\title{
A Design Manual for a Well-Logging Probe Capable of Measuring Tritium
}

C. Menninga

R. L. Brodzinski

October 1981

Prepared for the U.S. Department of Energy under Contract DE-AC06-76RLO 1830

Pacific Northwest Laboratory Operated for the U.S. Department of Energy by Battelle Memorial Institute 


\title{
NOTICE
}

This report was prepared as an account of work sponsored by the United States Government. Neither the United States nor the Department of Energy, nor any of their employees, nor any of their contractors, subcontractors, or thei employees. makes any warranty, express or implied, or assumes any legal liability or responsibility for the accueacy, completeness or usefulness of any information, apparatus, product or process disclosed, or represents that its use would not infringe privately owned rights.

The views. opinions and conclusions contained in this report are those of the contractor and do not necessarity represent those of the United States Government or the United States Department of Energy.

\author{
PACIFIC NORTHWEST LABORATORY \\ operated by \\ BATTELLE \\ for the \\ UNITED STATES DEPARTMENT OF ENERGY \\ Under Contract DE-AC06-76RLO 1830
}
Printed in the United States of America
Available from
National Technical Information Service United States Department of Commerce 5285 Port Royal Road Springfield. Virginia 22151

Price: Printed Copy $\therefore$ Microfiche $\$ 3.00$

NTIS

*Pages Selling Price

$001.025 \$ \$ 4.00$

026-050 \$4.50

051-07\$ $\$ 5.25$

$076-100 \quad \$ 6.00$

101-125 \$6.50

126-150 \$7.25

151-175 $\$ 8.00$

$176-200 \quad \$ 9.00$

$201-225 \quad \$ 9.25$

226-250 \$9.50

$251-275 \quad \$ 10.75$

$276-300 \quad \$ 11.00$ 
A Design Manual for a Well-Logging Probe Capable of Measuring Tritium

C. Menninga
R. L. Brodzinski

October 1981

Prepared for the U. S. Department of Energy under Contract DE-AC06-76RLO 1830 .

Pacific Northwest Laboratory

Richland, Washington 99352 


\section{TABLE OF CONTENTS}

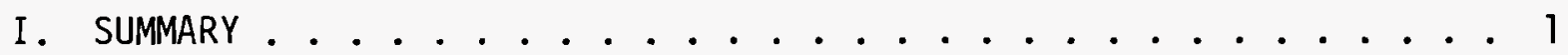

II. DESIGN CONCEPTS ....................... I

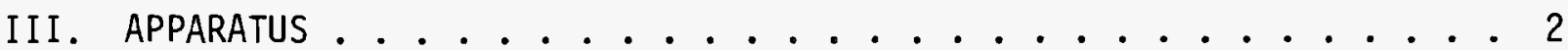

A. Sample Flow System. ............... 2

B. Sample Inlets................. 3

C. Cold Trap................... 4

D. Reducing Unit................ 4

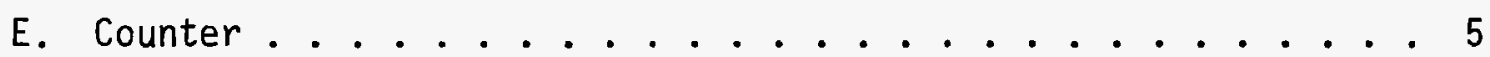

F. Casing. ................. 5

G. Connections to Surface. . . . . . . . . . 6

H. Surface Controls..................6 6

APPENDIX - DESIGN DRAWINGS FOR THE TRITIUM

WELL-LOGGING PROBE 


\section{A Design Manual for a Well-Logging Probe}

Capable of Measuring Tritium

C. Menninga and

R. L. Brodzinski

\section{SUMMARY}

The purpose of this instrument is to measure the concentration of tritium in situ in a well or bore hole. The instrument is designed to detect tritium at concentrations as low as terrestrial surface background. The instrument can sample air or water, and purify the sample from other radioactive nuclides and from chemical contaminants. The instrument will operate satisfactorily in the presence of a moderate gamma-ray background.

\section{DESIGN CONCEPTS}

Air sampling is done by passing the air over a palladium catalyst with a small amount of carrier hydrogen gas to convert all tritium to water, and the water is collected in a cold trap which is cooled thermoelectrically.

Water sampling is done by collecting water which diffuses through a tubing manifold made of Nafion (DuPont trademark - perfluorosulfonic acid product). Dry nitrogen carrier gas is passed through the tubing and then through the cold trap to collect the water.

The sample is released from the cold trap and is converted to an appropriate form for measuring tritium in a gas proportional counter which is surrounded by a shield counter filled with the same gas. The pressure is adjusted to 1 atmosphere, and an appropriate counting gas is added to form a 50-50 mixture of hydrogen and either ethane or propane at 2 atmospheres pressure.

Counting is done in anti-coincidence with the guard counter in order to reduce gamma-ray background interference. Radiations with energy higher than the maximum energy of the tritium beta particle $(18.6 \mathrm{keV})$ are discriminated against electronically. 


\section{APPARATUS*}

A. Sample Flow System

1. Materials and Components

The sample flow system consists entirely of stainless steel components. The gaseous sample is delivered through 0.125 -inch O.D. heavy wall tubing. The by-pass and exit lines to vacuum are 0.25-inch 0.D. heavy wall tubing. The tubing sections are as short as possible in order to minimize sample hold-up. Connections between tubing and valves or components are made with Swagelok (trademark) fittings.

2. Flow Control Valves

Sample flow is produced by evacuating appropriate sections of the system, and is controlled and directed by a system of Skinner (trademark) miniature solenoid valves. The valves are normally closed, and are opened by applying 115 volts of alternating electric current controlled from the surface. A typical subassembly of valves and tubing (without electrical connections made) is shown in Figure 1.

3. Pressure Gauge

It is necessary to measure the pressure at various points in the system in order to operate the instrument properly. A remote readout gauge is incorporated into the system with the transducer in the welllogging probe and the readout instrument at the surface. The transducer is opened to the various points of interest by solenoid valves.

4. Component Arrangement

When the instrument is in operating position, the sample reducing unit must be at the lower end for convenience in replenishing materials which are consumed during operation. The cold trap is placed as close to the reducing unit as possible to minimize the potential holdup of sample between them. Similarly, the counter is placed as

*Design drawings for the apparatus are found in the Appendix. 
close as possible to the reducing unit.

The remainder of the components are arranged so as to occupy minimum space between the counter and the upper end of the instrument.

\section{B. Sample Inlets}

The air and water sample inlets are at the lower end of the instrument. Three pieces of 0.125-inch tubing extend through the bottom of the casing, with a seal consisting of a pass-through Swagelok fitting equipped with Teflon (trademark) ferrules. Air is sampled through one of these pieces of tubing, and the water sampler is attached to the other two (Fig. 2). The sampling devices are protected by a housing which is open at the bottom and which has openings in the sides near the top to allow free flow of air or water through the sampling region.

1. Air samples are drawn into the instrument through a sintered stainless steel filter. Hydrogen gas is mixed with the air sample at the rate of $0.021 \mathrm{iter}$ per minute. The air-hydrogen mixture is passed over a palladium catalyst at ambient temperature in order to

- convert all hydrogen present to water.

The rate of air flow is regulated by a metering valve which has been preset to pass two liters of air per minute with the inlet at atmospheric pressure and the outlet at moderate vacuum.

The air is then passed through the cold trap to extract the sample in the form of water.

The air sample inlet is equipped with a float valve so that no liquid water will be drawn into the system if the instrument is lowered into water. The pressure change in the air sampling stream which results from closing the float valve will indicate that the instrument has reached the water level in the sampling environment.

2. The liquid water sampler consists of a manifold of eight pieces of Nafion (trademark) perfluorosulfonic acid polymer tubing eight 
inches in length. The tubing has a nominal 0.035 in. I.D. and a 0.007 in. wall thickness and is sealed into stainless steel fittings with epoxy cement.

Dry nitrogen gas is passed through the manifold at the rate of two liters per minute. Water in contact with the outside surface of the tubing diffuses through the wall and is carried away as water vapor in the stream of nitrogen gas which then passes through the cold trap where the sample is extracted in the form of water.

C. Cold Trap

The cold trap consists of a rectangular copper tank with a volume of about $15 \mathrm{~cm}^{3}$. This trap is sandwiched between two thermoelectric devices (Cambion \#801-2001-01) for c001ing and heating. These are sandwiched between two copper heat sinks which are water cooled. All contact surfaces are coated with thermally conductive grease, and the assembly is clamped together (Fig. 3).

The thermistors for the thermoelectric control unit and the thermistor for the remote temperature indicator are mounted in contact with the cold trap. The entire unit is packed in thermal insulation.

The tubing and valve connections between the cold trap and the reducing unit are wrapped in heating tape so that the entire sample path can be heated while transferring the sample from the cold trap to the reducing unit.

D. Reducing Unit

Two alternatives are being investigated.

1. The preferred method incorporates a reducing furnace that consists of a stainless cylinder 1 inch in diameter and 7 inches 1ong, with welded end pieces and 0.5 inch tubing inlet and outlet. This cylinder is surrounded by Lindberg furnace heating elements packed in thermal insulation and covered with fiberglass sleeving (Fig. 4). This furnace contains magnesium chips which convert the water sample to 
hydrogen gas. Tubing connections are made in such a way that the furnace can be disassembled for recharging with magnesium chips or turnings.

2. The secondary method consists of a unit which contains calcium carbide for converting the water sample to acetylene. The acetylene is introduced through a metering valve to a small tank containing a Pd catalyst, and a slight excess of hydrogen gas is introduced simultaneously to convert the acetylene to ethane.

The second al ternative requires an additional tank and valves to measure sample size, but it does not require the furnace heating unit. E. Counter

The counter is an 0eschger-type proportional counter with a total gas volume of about $1000 \mathrm{~cm}^{3}$. The inner counter has a volume of $250 \mathrm{~cm}^{3}$ and is separated from the guard counter by a perforated stainless steel sleeve which is supported by Teflon end pieces and spacers. The inner counter has a single central collector wire, and the guard counter has six collector wires all of 0.002 inch stainless steel.

The body of the counter is made from 2-inch Schedule 10 stainless steel pipe. The pipe is threaded on the inside for 0.375 inches from both ends. End plugs with Teflon gaskets seal the counter. Gas sample ports are provided in both end plugs, and two insulated electrical connectors are soldered into the upper end plug (Fig. 5).

The counter is equipped with two preamplifiers, one for the inner counter and one for the guard counter. The preamplifiers are placed as close to the counter electrical connectors as possible, and are surrounded by a stainless steel sleeve for electrical shielding and for physical protection.

\section{F. Casing}

The casing for the apparatus consists of an upper section 10 feet long and a lower section 16 inches in length. The upper section is made from 2.5-inch Schedule 5 stainless steel pipe, and houses all the components except the furnace and sampling apparatus. 
The top end piece is attached to the casing with four machine screws and has an 0-ring seal to make the casing watertight. There are six threaded holes through the end piece for attaching tubing and hose connectors for gas and water supply to the probe. A section of 1-inch stainless steel tubing 1.5 inches long is welded into the end piece for attaching the cable carrying electrical connections to the surface. Two eye-bolts are fastened to the end piece for attaching the wire rope which is used to raise and lower the probe.

The lower section of the casing houses the furnace and is attached to the upper section by means of an inside connector ring. Both sections are fastened to the ring with machine screws and 0-ring seals to make watertight connections. The lower end piece is welded into the casing and has three tapped holes for tubing connections to the sampling apparatus (Fig. 2). This construction makes it possible to reach the reducing furnace for recharging by removing the sampling apparatus and the lower casing section while leaving the remainder of the probe assembled.

G. Connections to Surface

Sample processing within the probe is controlled from the surface. Electrical connections are made through a multi-connector cable which contains six AWG \#16 conductors, 45 AWG \#22 conductors, two TG62/U shielded coaxial signal leads, and one RG59/U shielded coaxial high voltage lead.

The probe is supplied with cooling water through reinforced rubber hoses. Tygon tubing is used to supply the probe with gaseous hydrogen, nitrogen, and propane. Heavy-wall rubber vacuum tubing is used to pump gases from the probe through a vacuum pump at the surface.

H. Surface Controls

The solenoid valves in the probe are controlled by switches which are mounted on a panel at the surface. The switches are arranged along a flow diagram which outlines the passage of a sample through the apparatus.

The controls for the cold trap are supplied by Cambridge Thermionic Corporation. A bipolar controller (Model \#809-3020-01) with range extender (Model \#809-3048-08) provides temperature control with a range 
from $-20^{\circ} \mathrm{C}$ to $+125^{\circ} \mathrm{C}$ with a stability of $\pm 0.1^{\circ} \mathrm{C}$. A digital temperature indicator (Model \#811-7204-01/02) is used to indicate the temperature of the cold trap.

The heating tape between the cold trap and the reducing furnace is controlled manually by means of a Variac at the surface.

The magnesium-packed reducing furnace is equipped with a chromelalumel thermocouple and a proportional controller (Brown Pyrovane type). This system provides temperature control ranging up to $1000^{\circ} \mathrm{C}$ with a stability of $\pm 10^{\circ} \mathrm{C}$.

The pressure sensor is supplied by Precise Sensors. The range is from 0 (vacuum) to 3 atmospheres of pressure. The accuracy is $\pm 0.5 \%$ of the range. The digital readout unit is at the surface.

The counter is equipped with two preamplifiers whose power requirements are supplied from the surface. A high-voltage power supply at the surface provides the bias for the counter collector wires. The signals from the preamplifiers are processed through a coincidence - anticoincidence circuit. A scaler is used to record the counts detected during the counting period.

The gases are supplied to the probe from pressurized tanks equipped with appropriate regulators. Cooling water is circulated through the cold trap heat sink with a small centrifugal pump.

The entire apparatus requires approximately 3 kilowatts of power. For field use this is supplied by gasoline-powered generators. The power for the counter, preamplifiers, and associated electronics is supplied by an independent unit in order to obtain maximum stability for that part of the apparatus. 


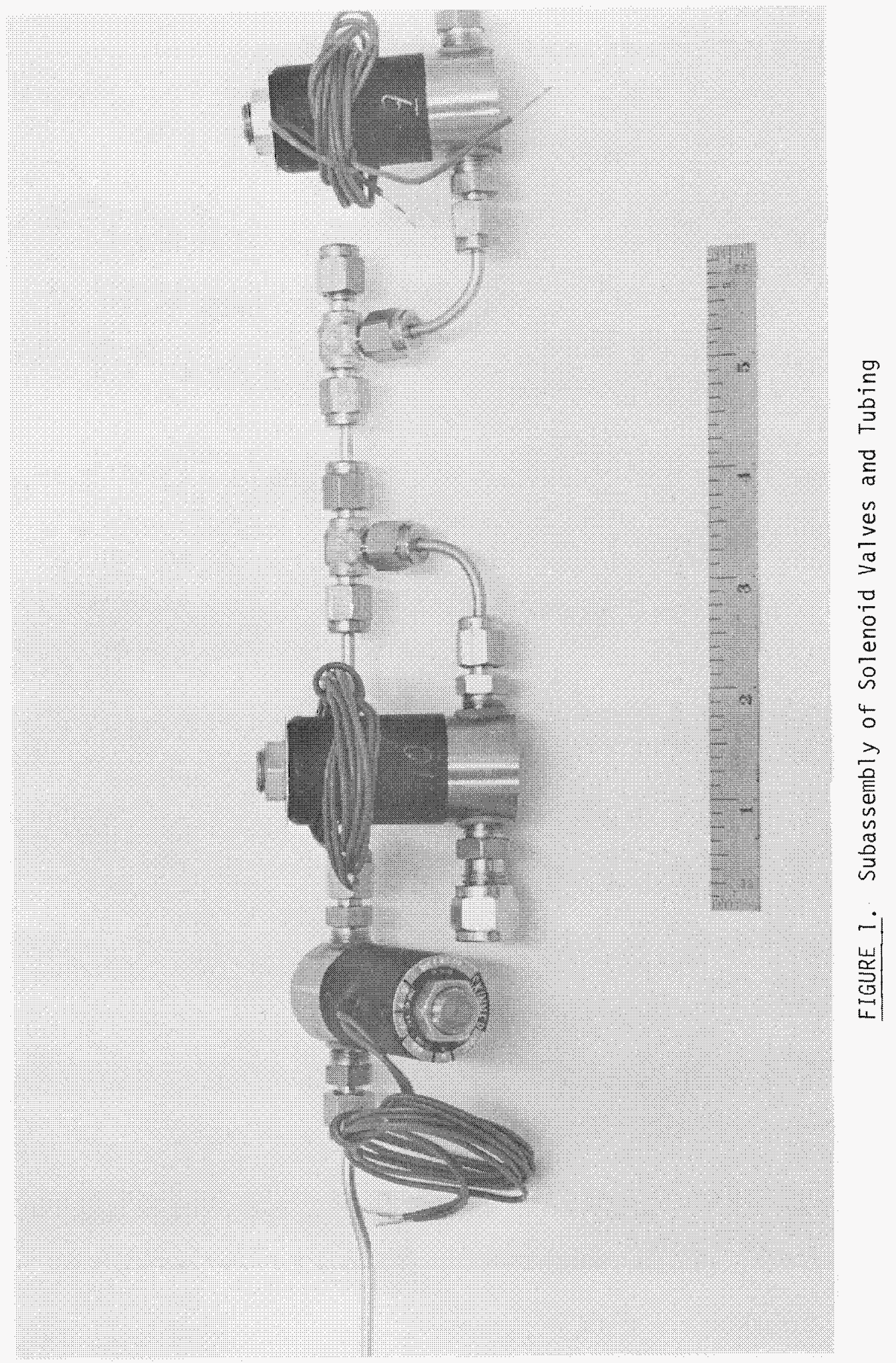




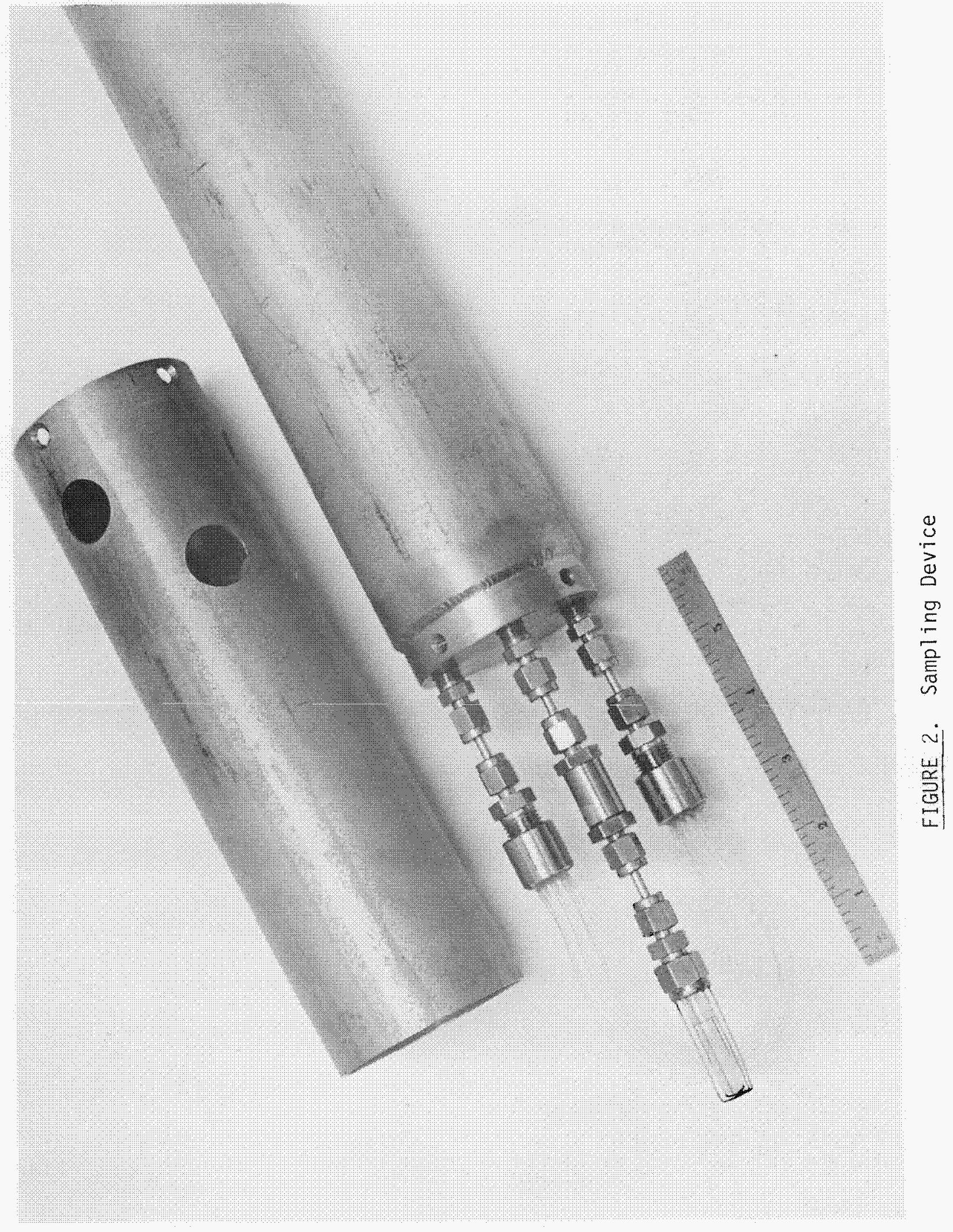




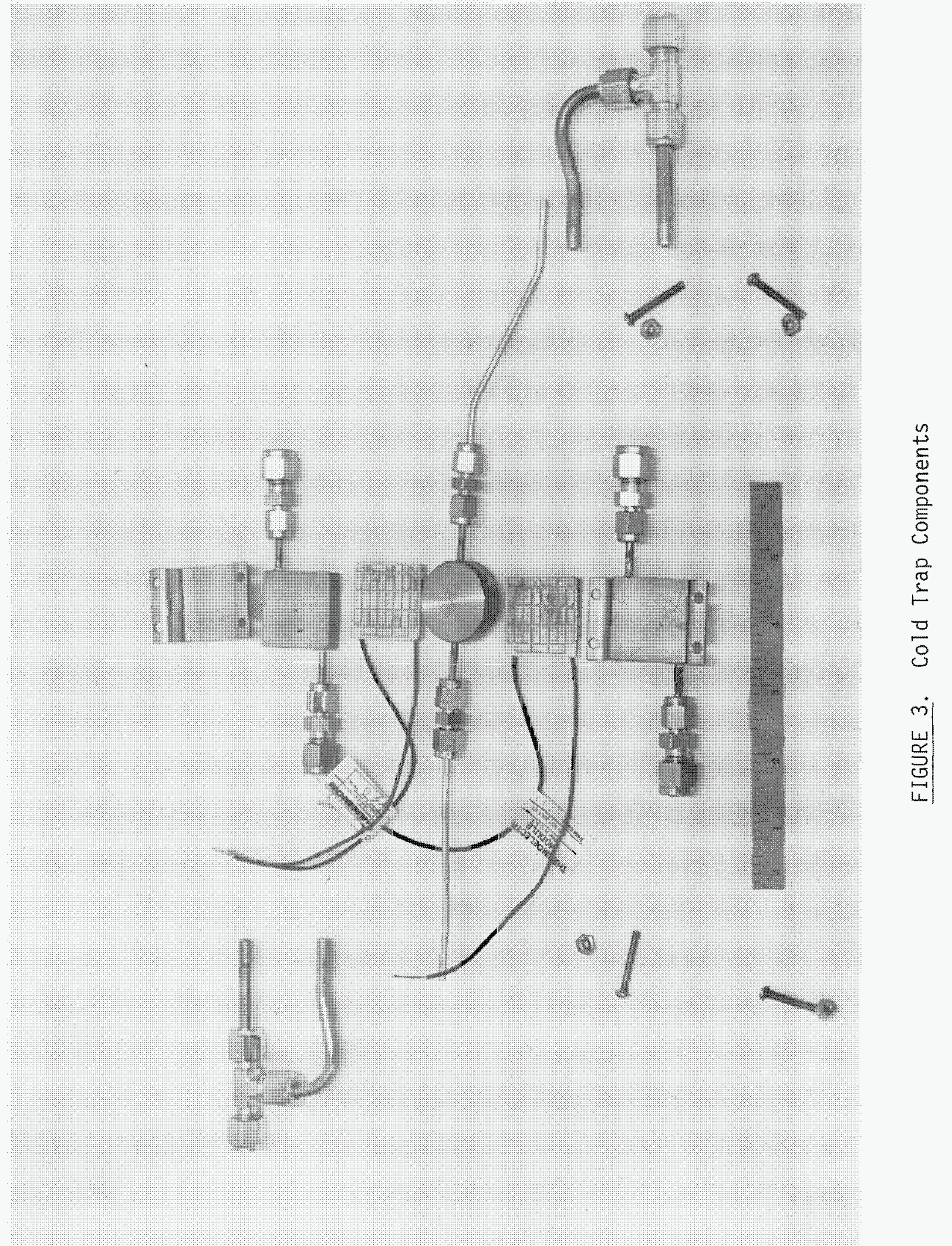




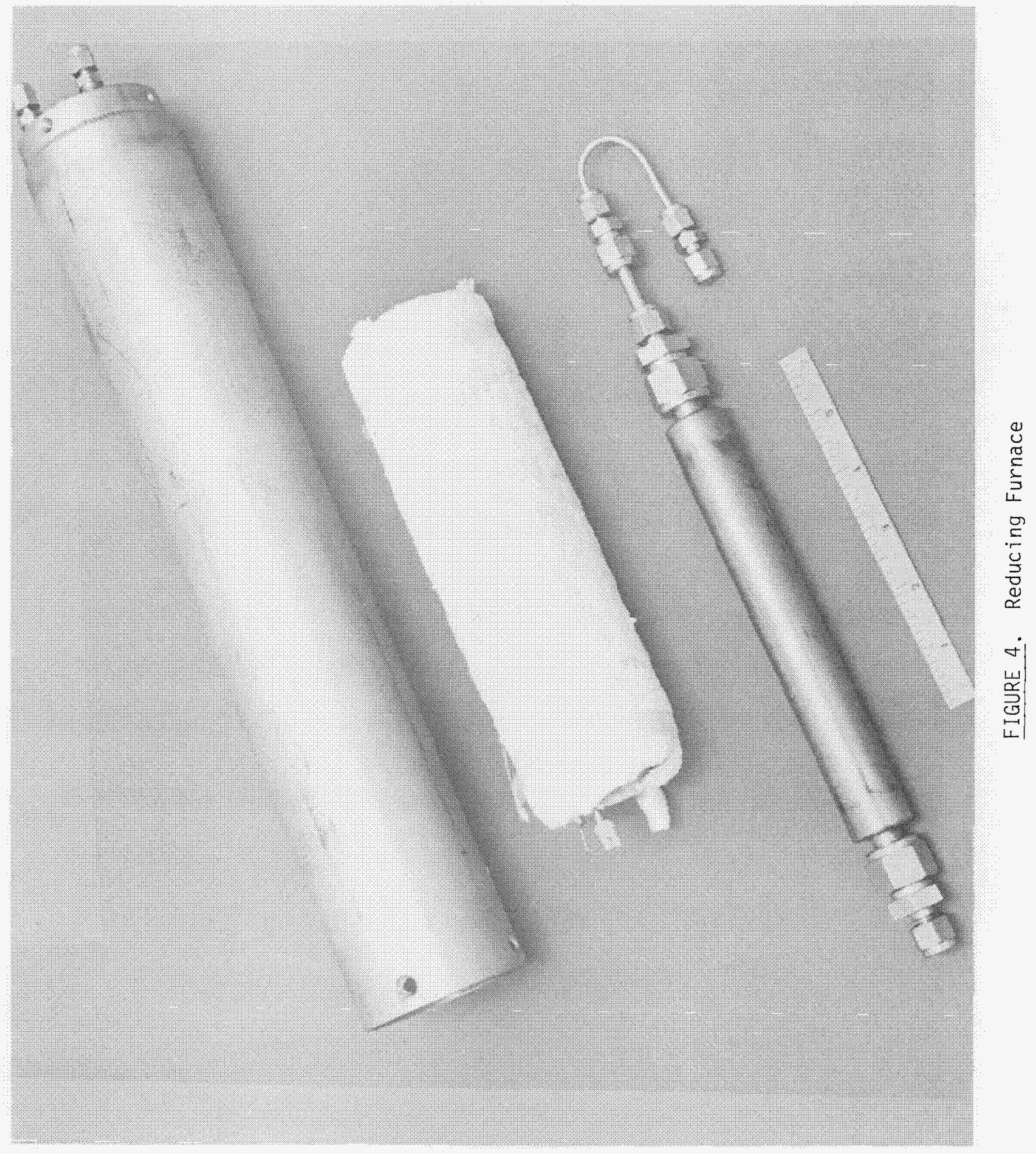




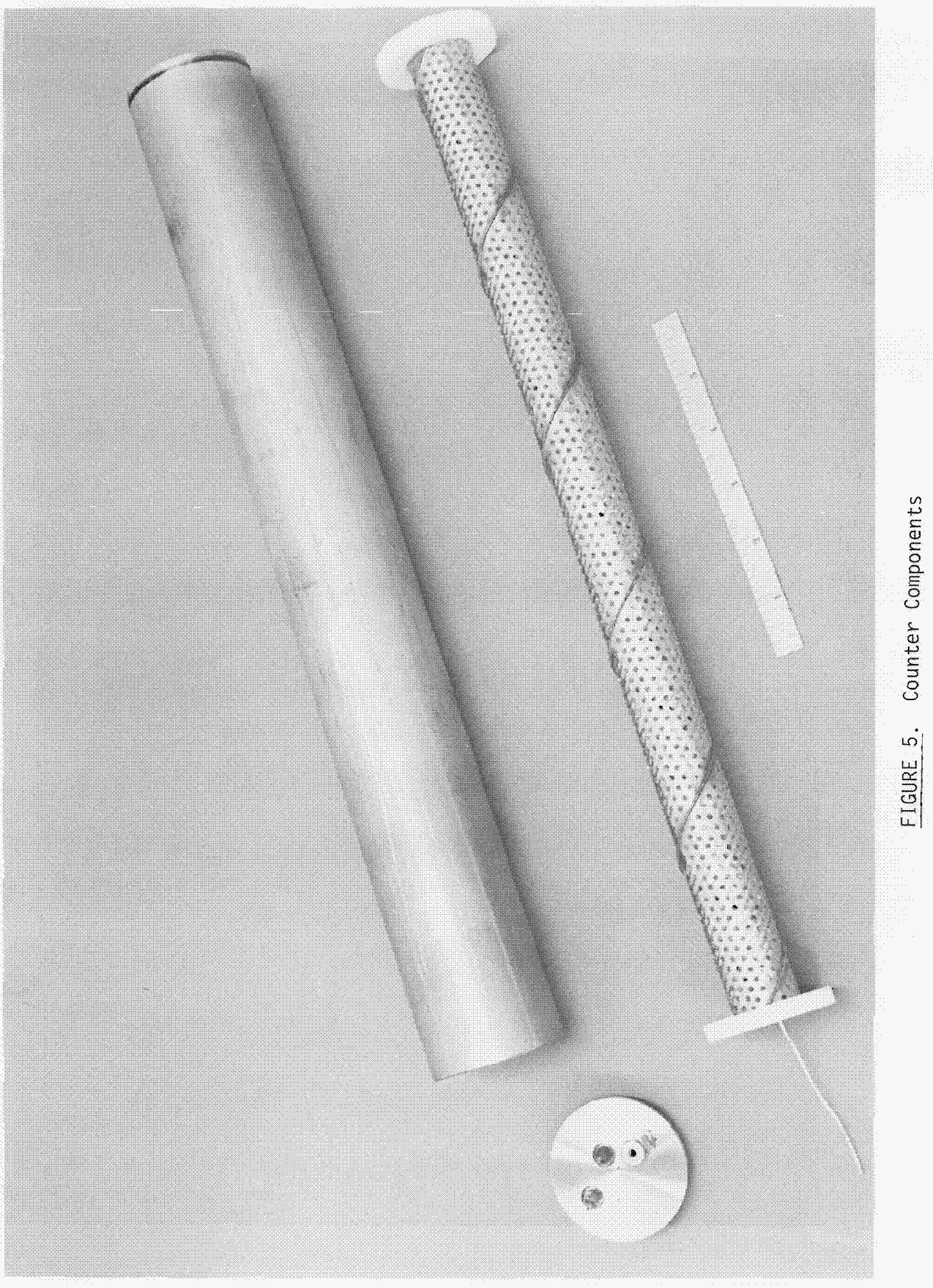


APPENDIX

DESIGN DRAWINGS FOR THE TRITIUM WELL-LOGGING PROBE 


\section{LIST OF DRAWINGS}

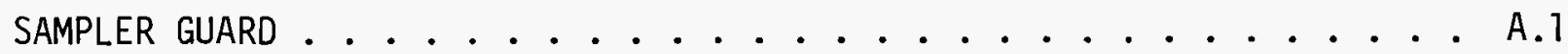

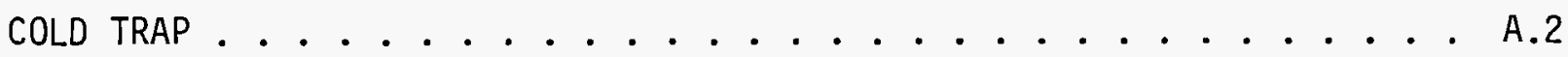

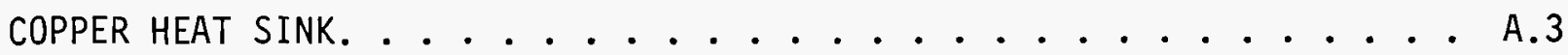
REDUCING FURNACE. . . . . . . . . . . . . . . A.4 PROPORTIONAL COUNTER - OUTER BODY . . . . . . . . . A.5 PROPORTIONAL COUNTER - TEFLON INSULATORS. . . . . . . . . A-6 PROPORTIONAL COUNTER - TEFLON INSULATORS. . . . . . . . . A.7 PROPORTIONAL COUNTER - FRONT END PLUG . . . . . . . . . . A.8 PROPORTIONAL COUNTER - BACK END PLUG. . . . . . . . . . . A.9 TOP END PIECE FOR INSTRUMENT CASING . . . . . . . . . . . A.10 CONNECTOR RING BETWEEN UPPER CASING AND HEATER SLEEVE . . . . . . A.11

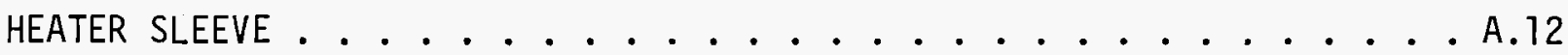
HEATER SleEVE END PIECE . . . . . . . . . . . . A.13

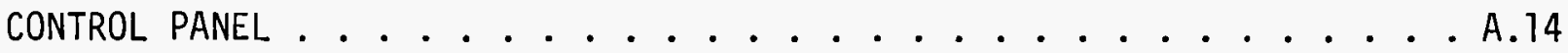




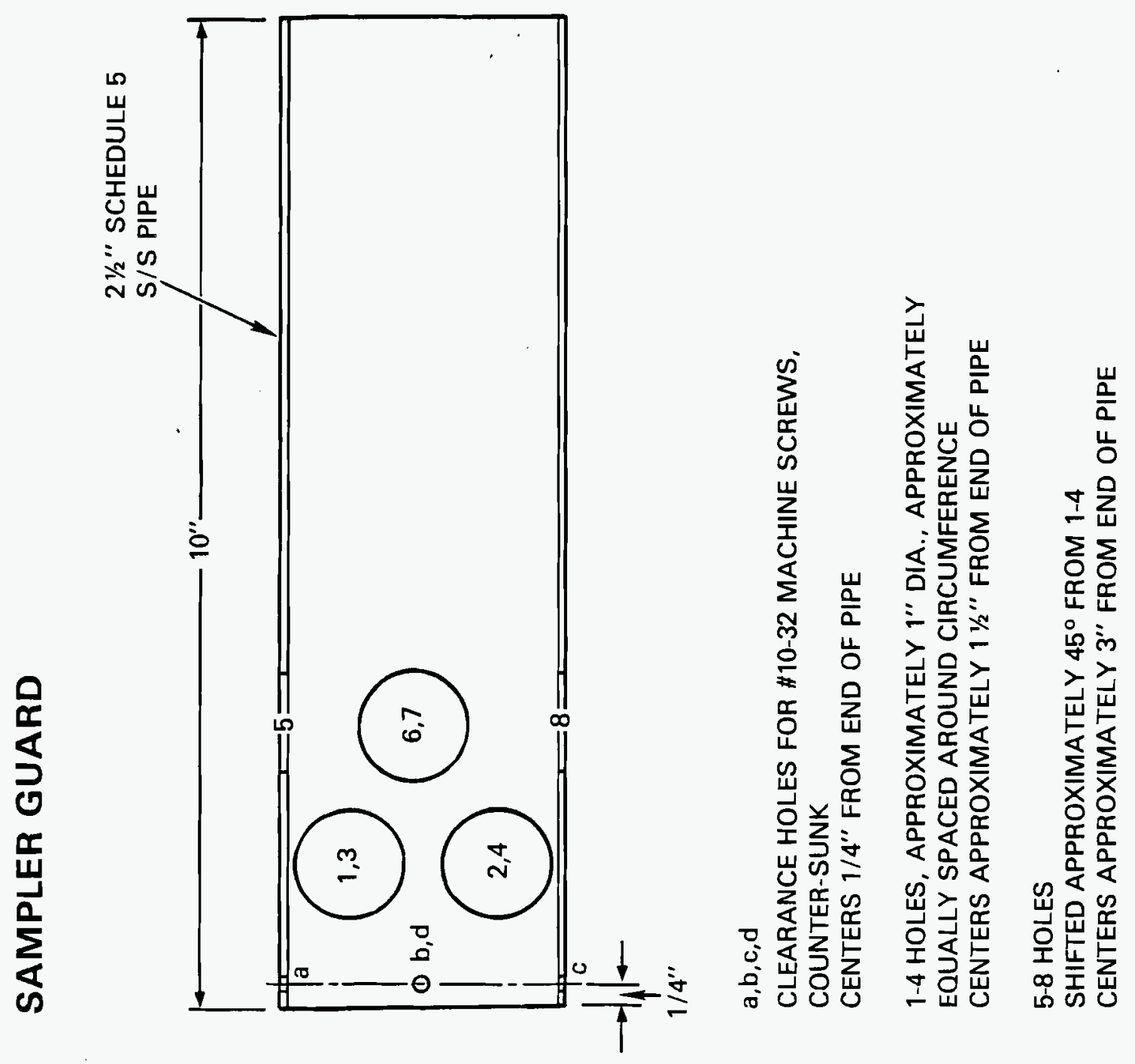

A. 1 


\section{COLD TRAP}

ONE HALF

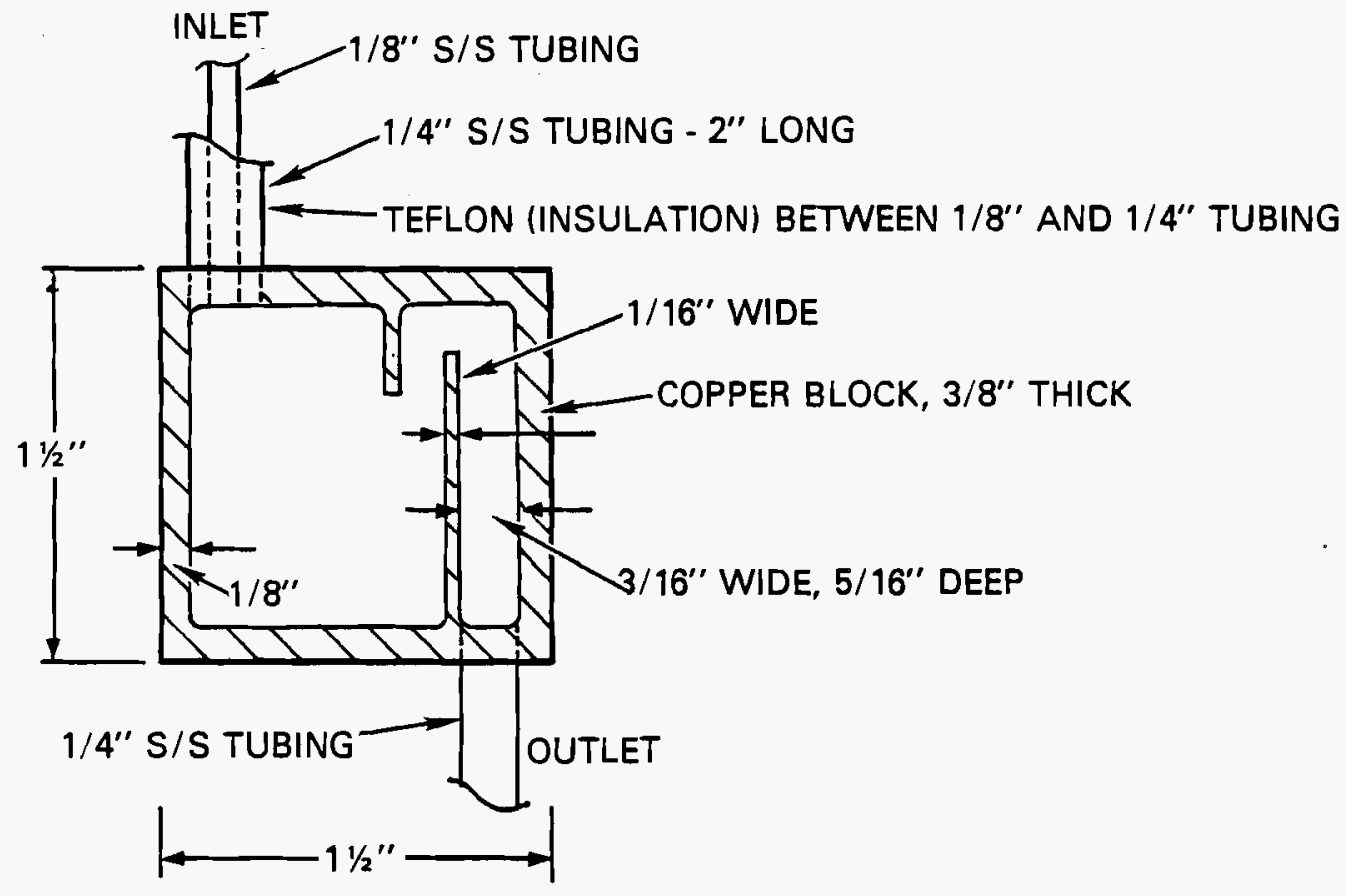

OTHER HALF

MIRROR IMAGE MILLED DESIGN

NO S/S TUBING

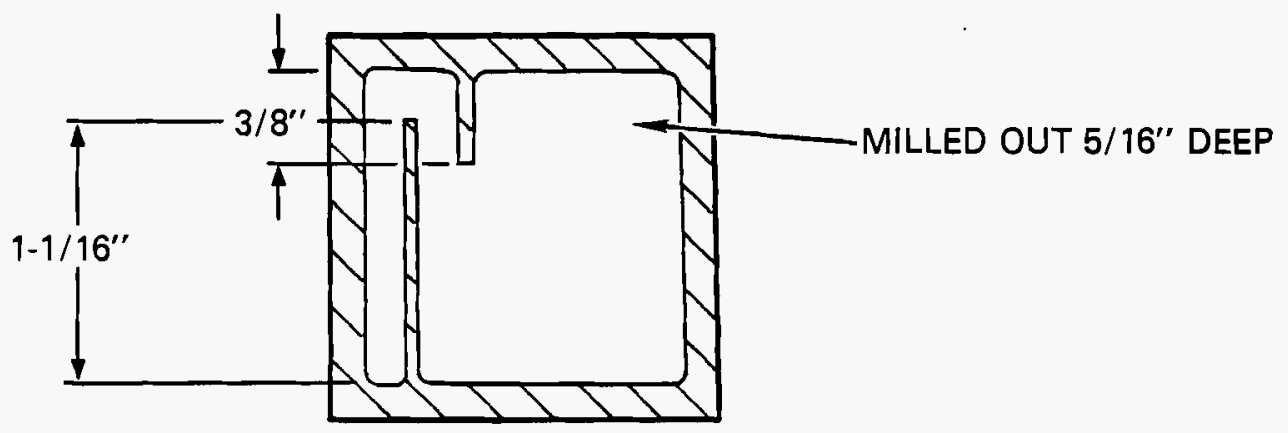

$1 / 4 "$ S/S TUBING SEALED INTO COPPER BLOCK WITH

LOW TEMPERATURE SOLDER

S/S SCREEN IN OUTLET CHANNEL

TWO HALVES SOLDERED TOGETHER 


\section{COPPER HEAT SINK}

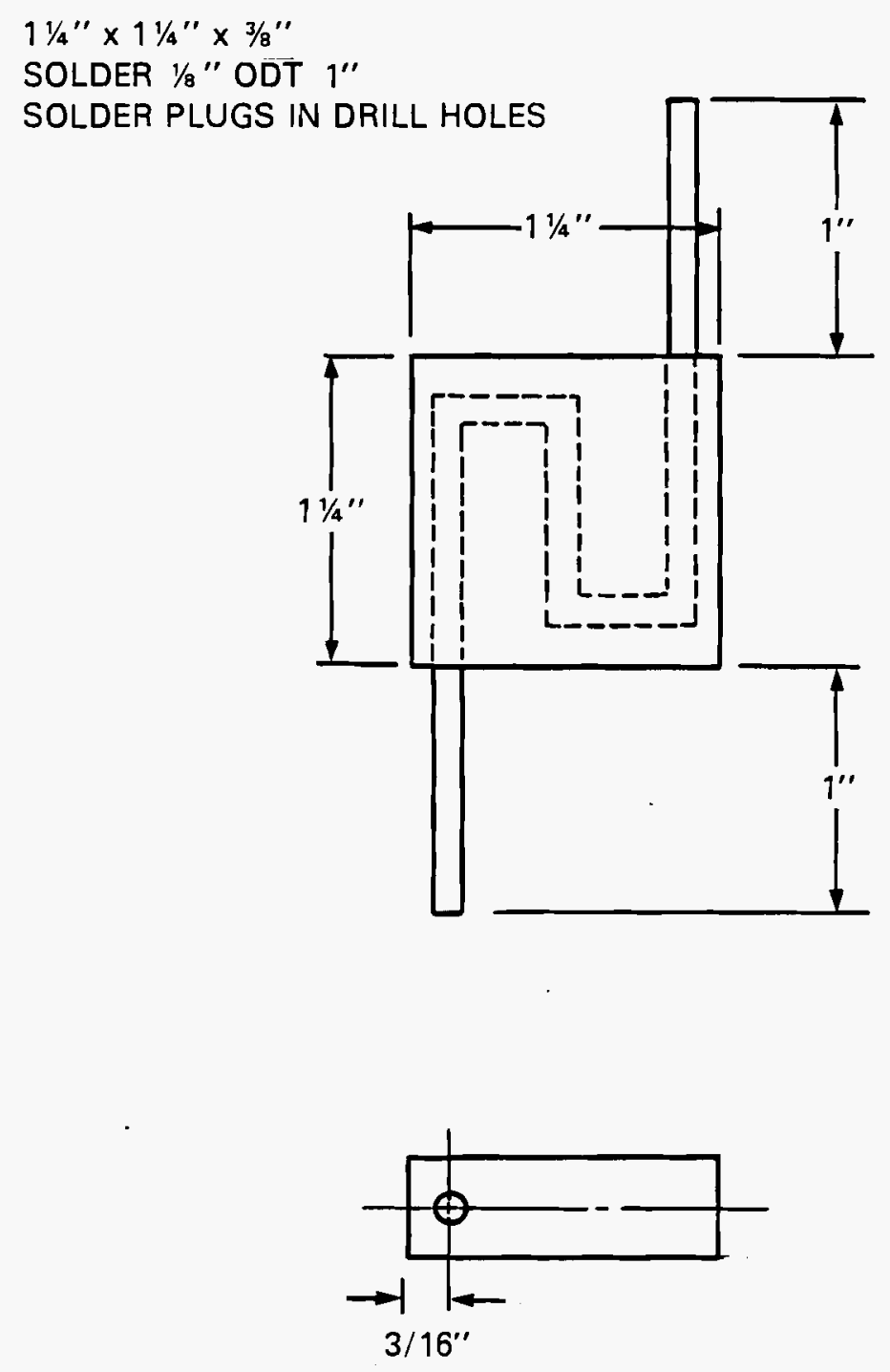

A. 3 


\section{REDUCING FURNACE}

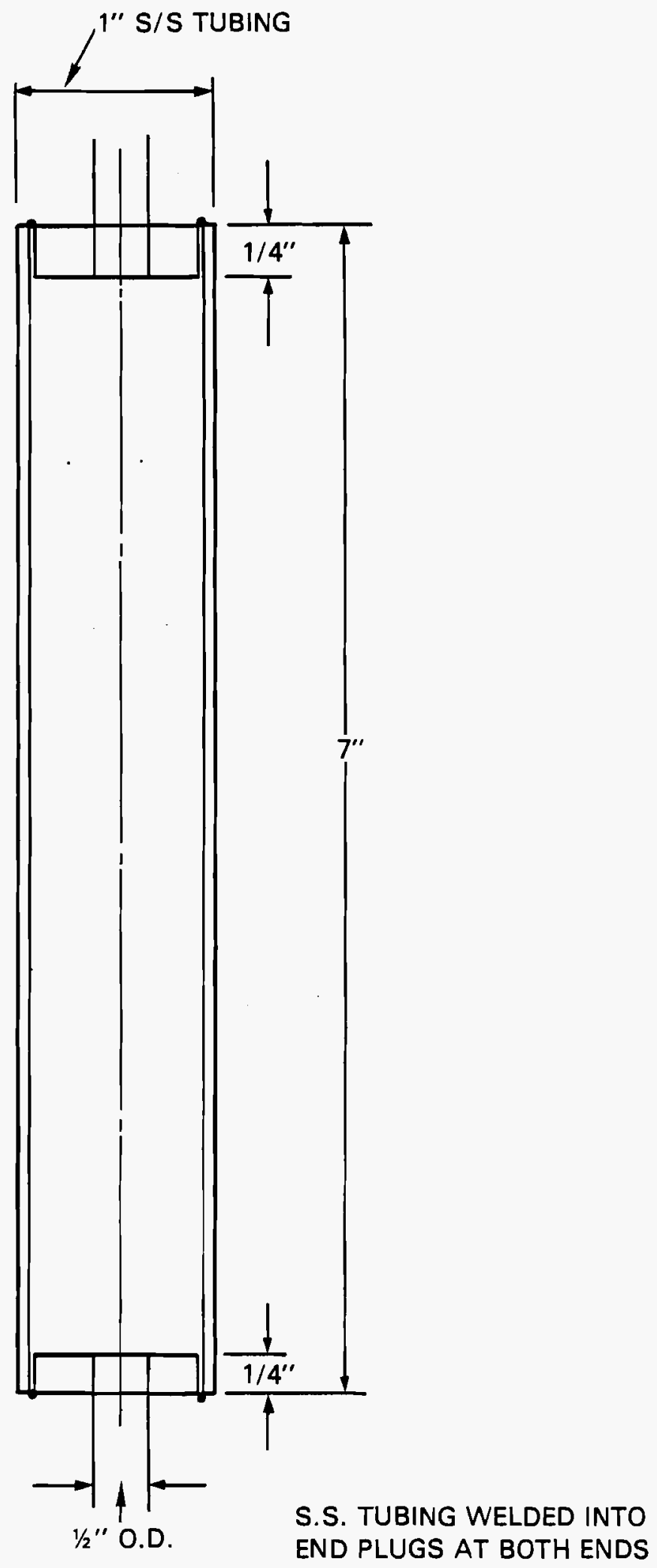

A. 4 
PROPORTIONAL COUNTER - OUTER BODY
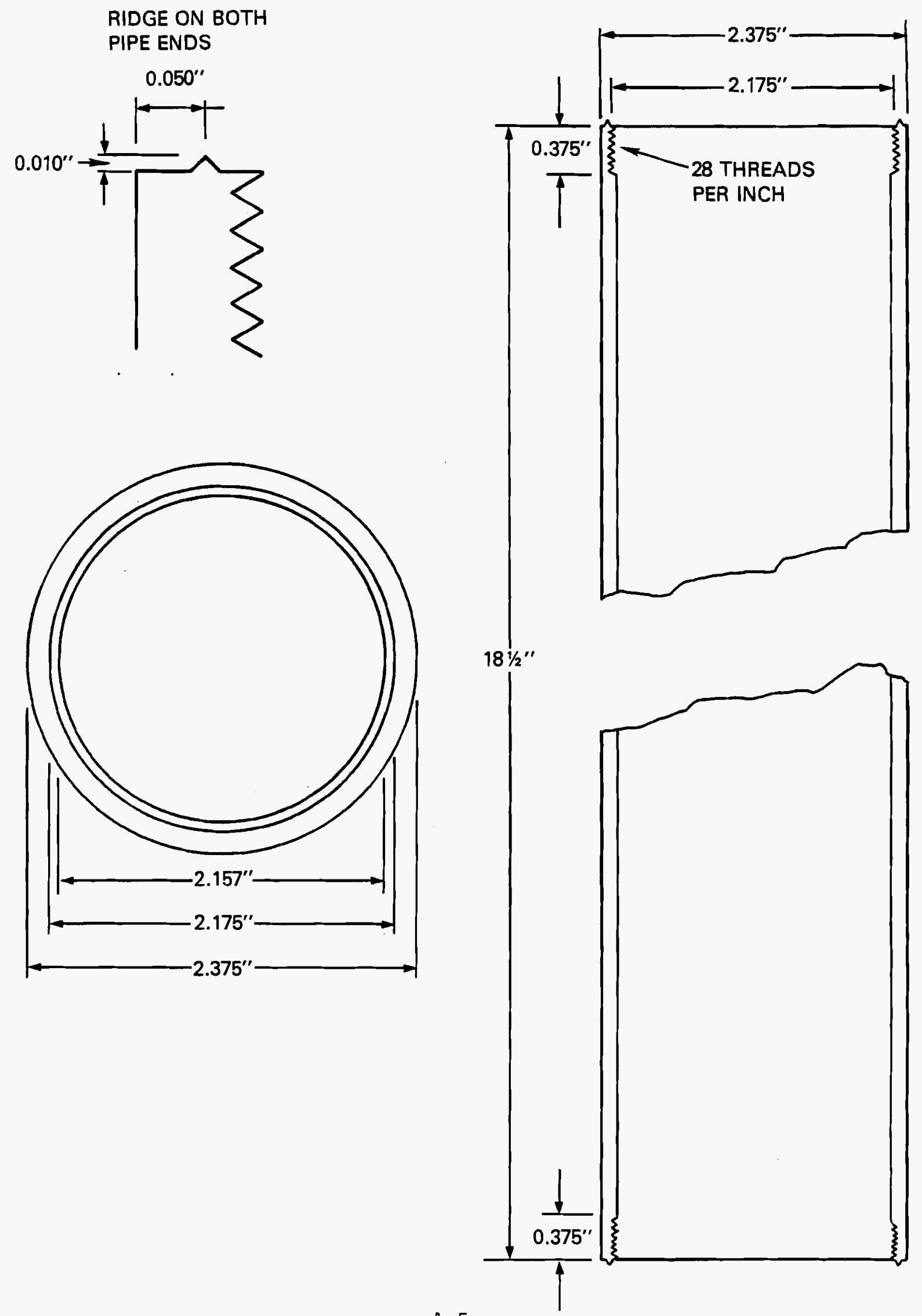


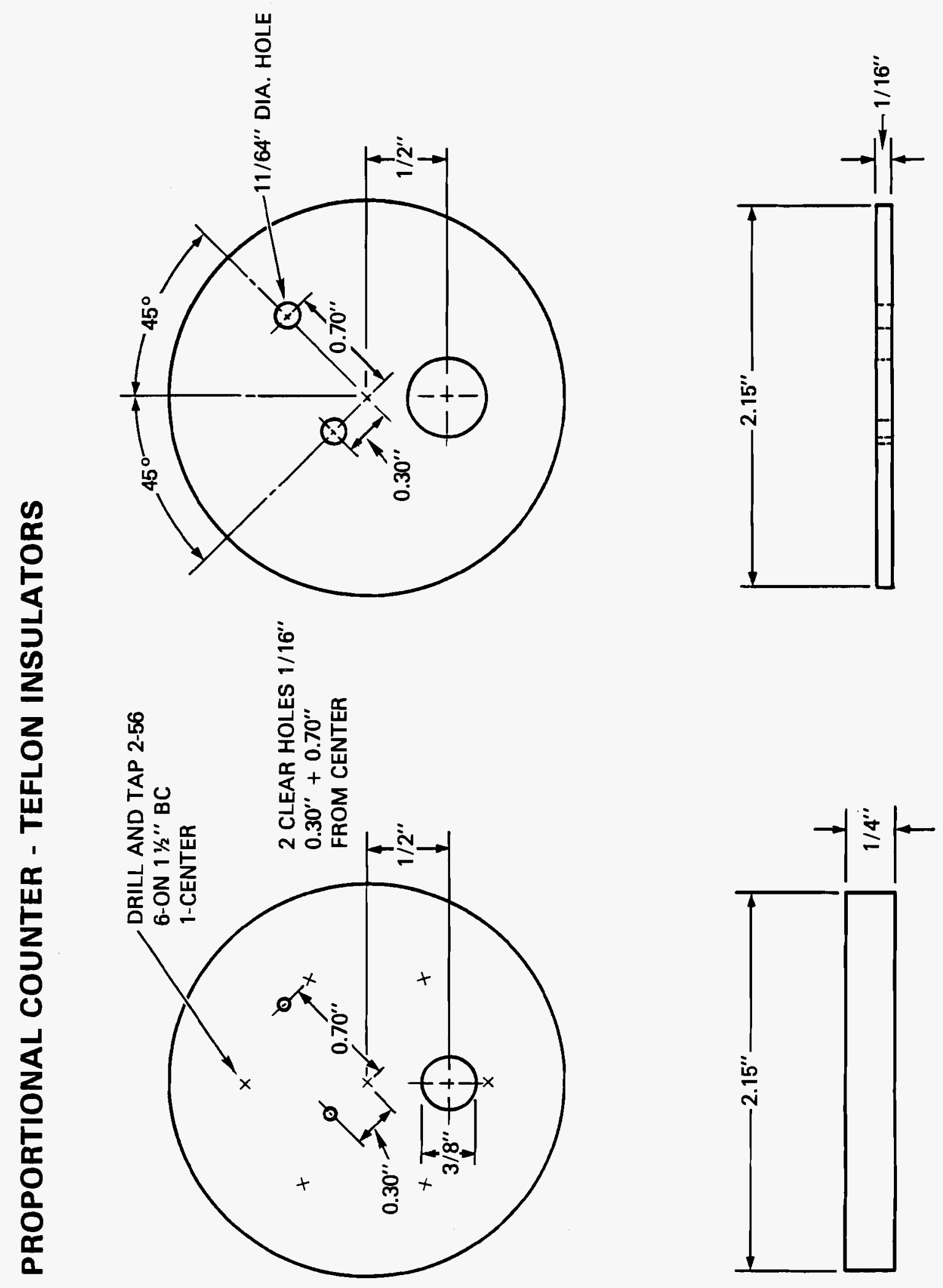



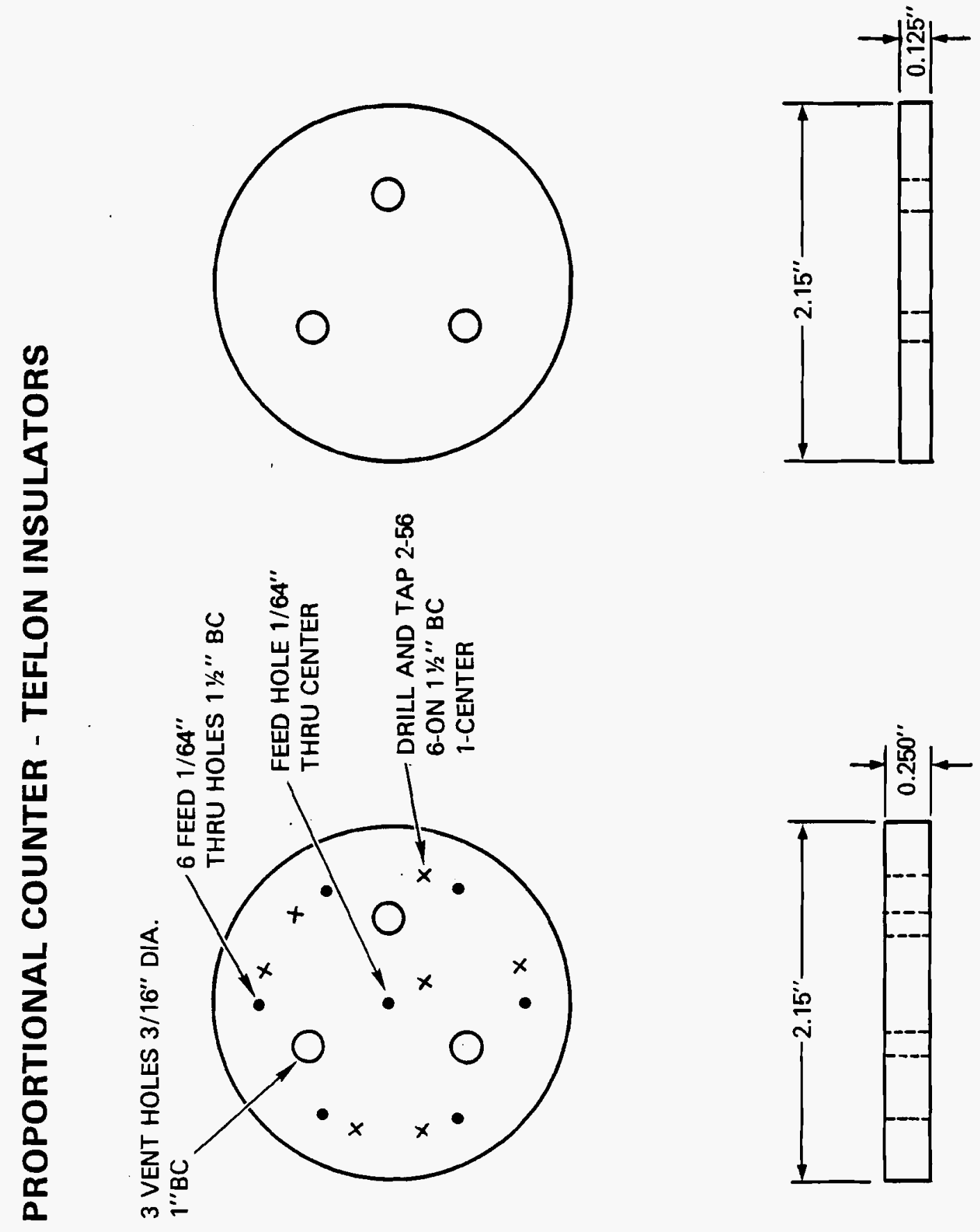


\section{PROPORTIONAL COUNTER - FRONT END PLUG}
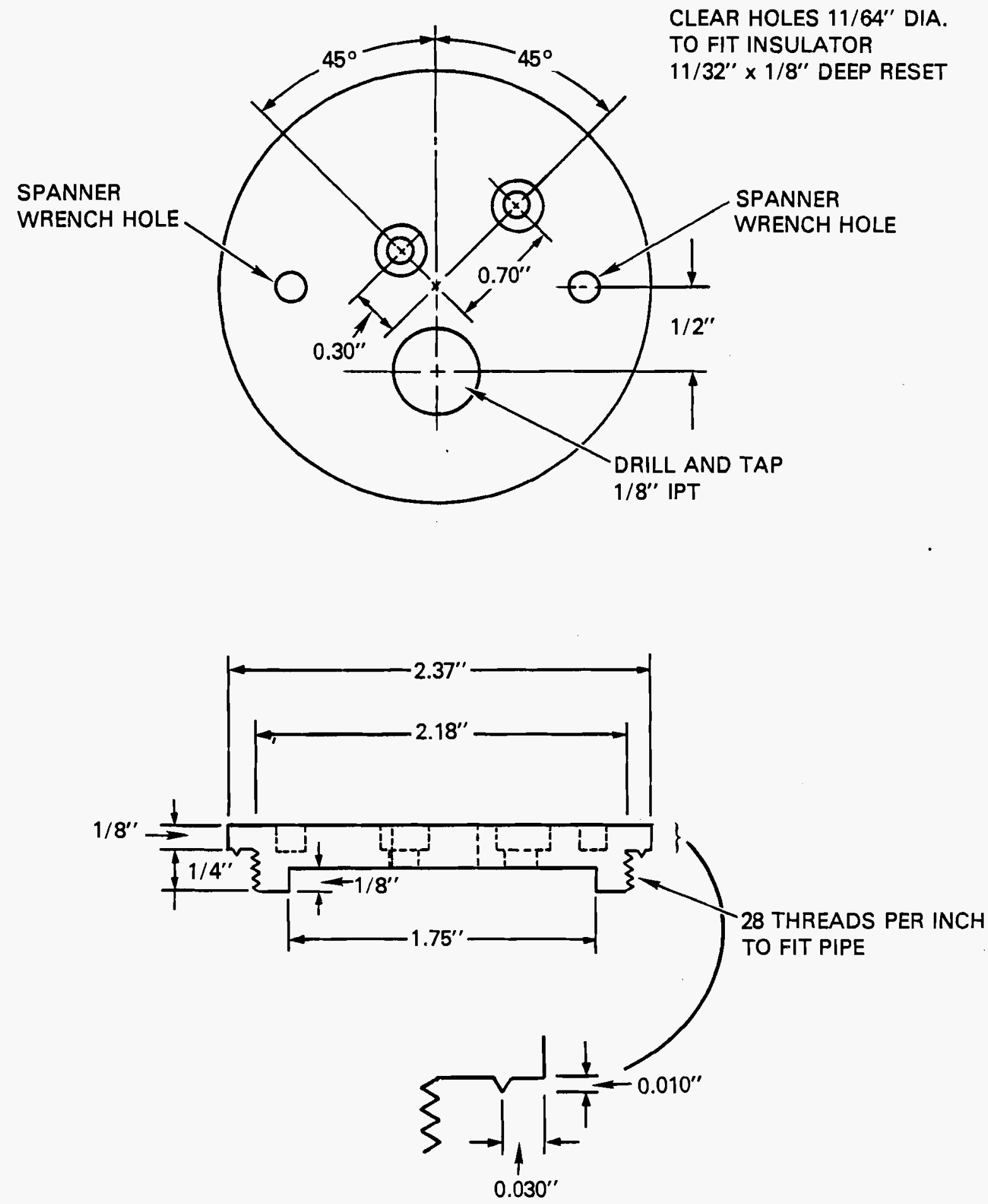

A. 8 


\section{PROPORTIONAL COUNTER - BACK END PLUG}
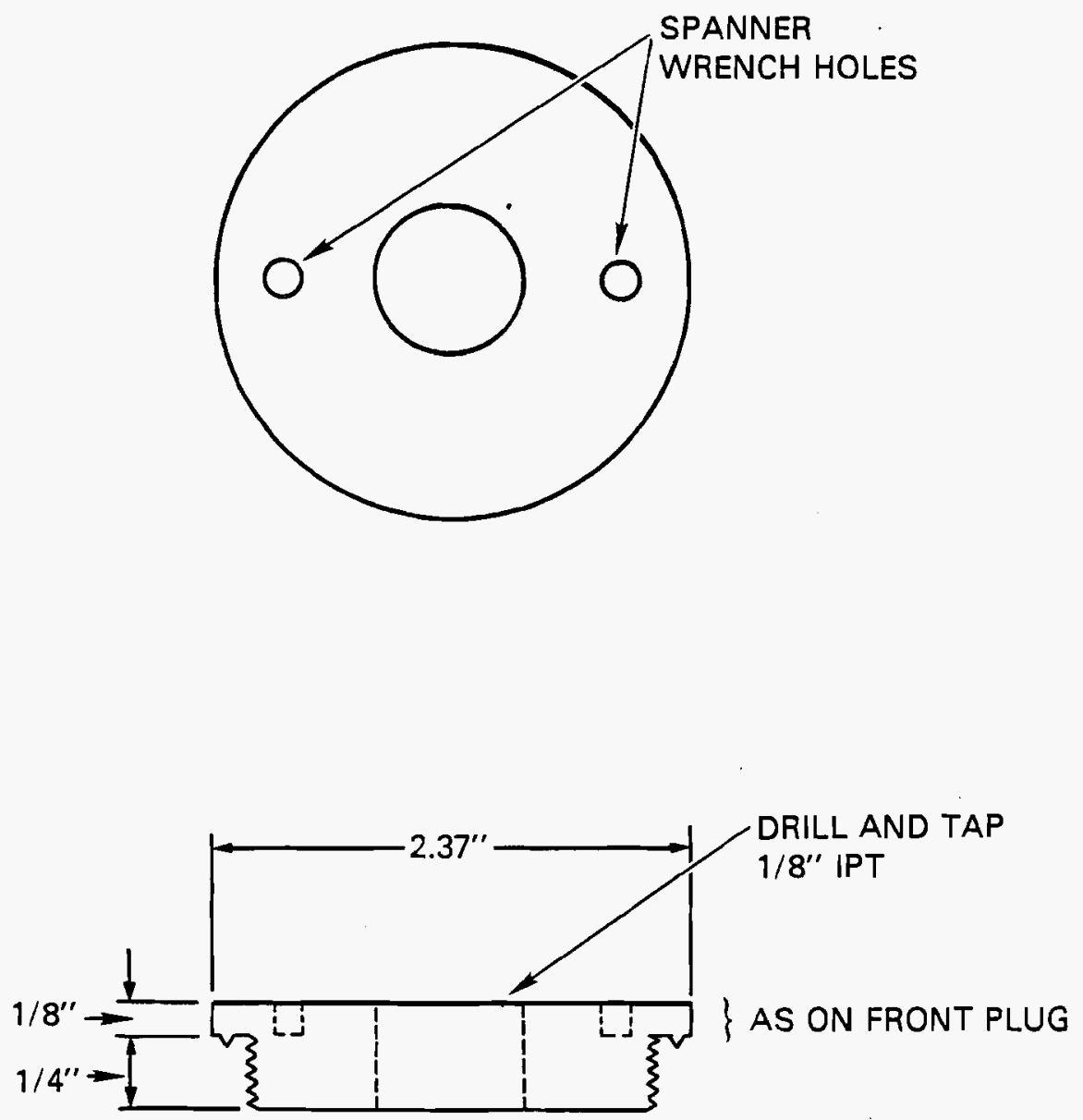


\section{TOP END PIECE FOR INSTRUMENT CASING}
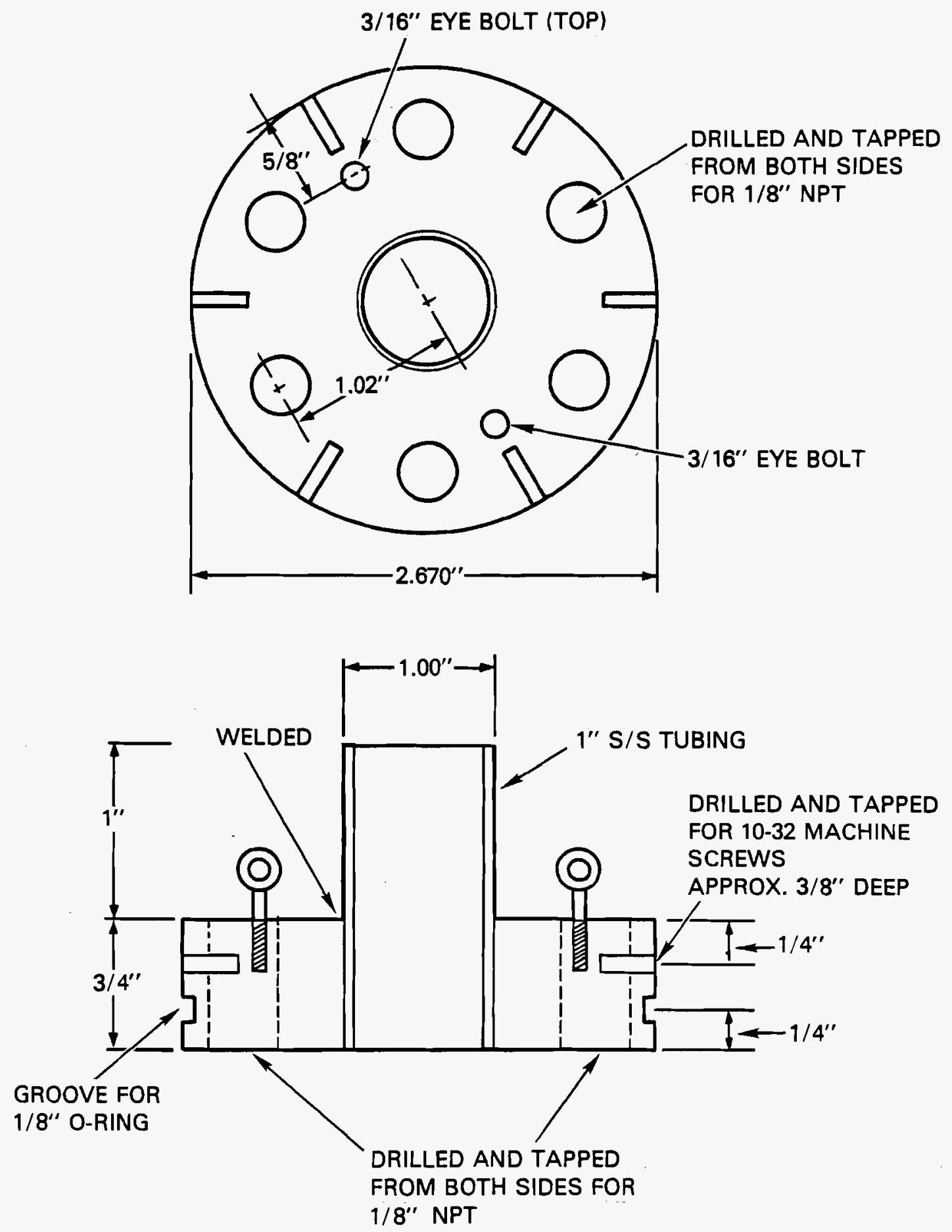


\section{CONNECTOR RING BETWEEN UPPER CASING}

AND HEATER SLEEVE
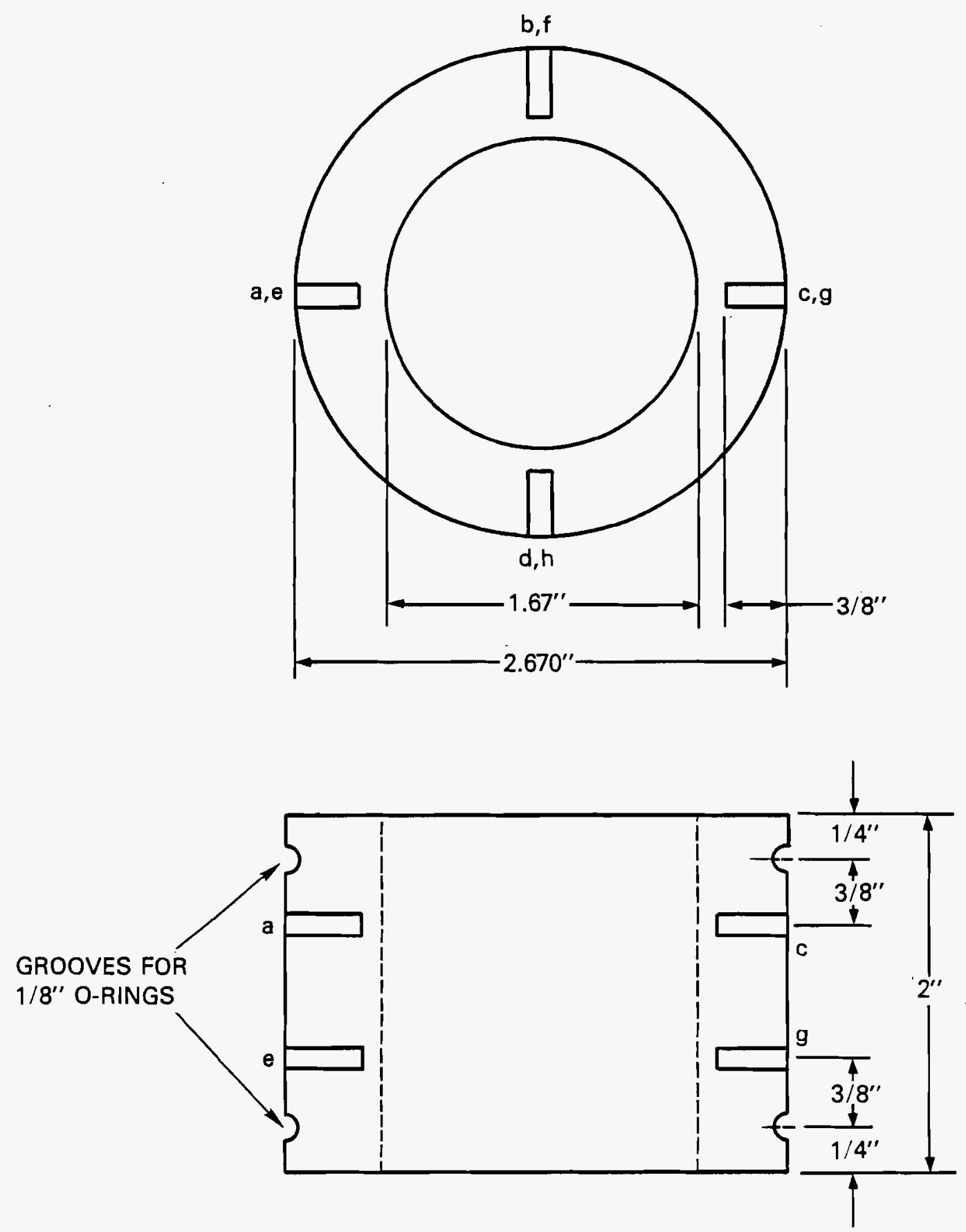

a-g: DRILL AND TAP FOR 10-32 MACHINE SCREW, 3/8" DEEP 


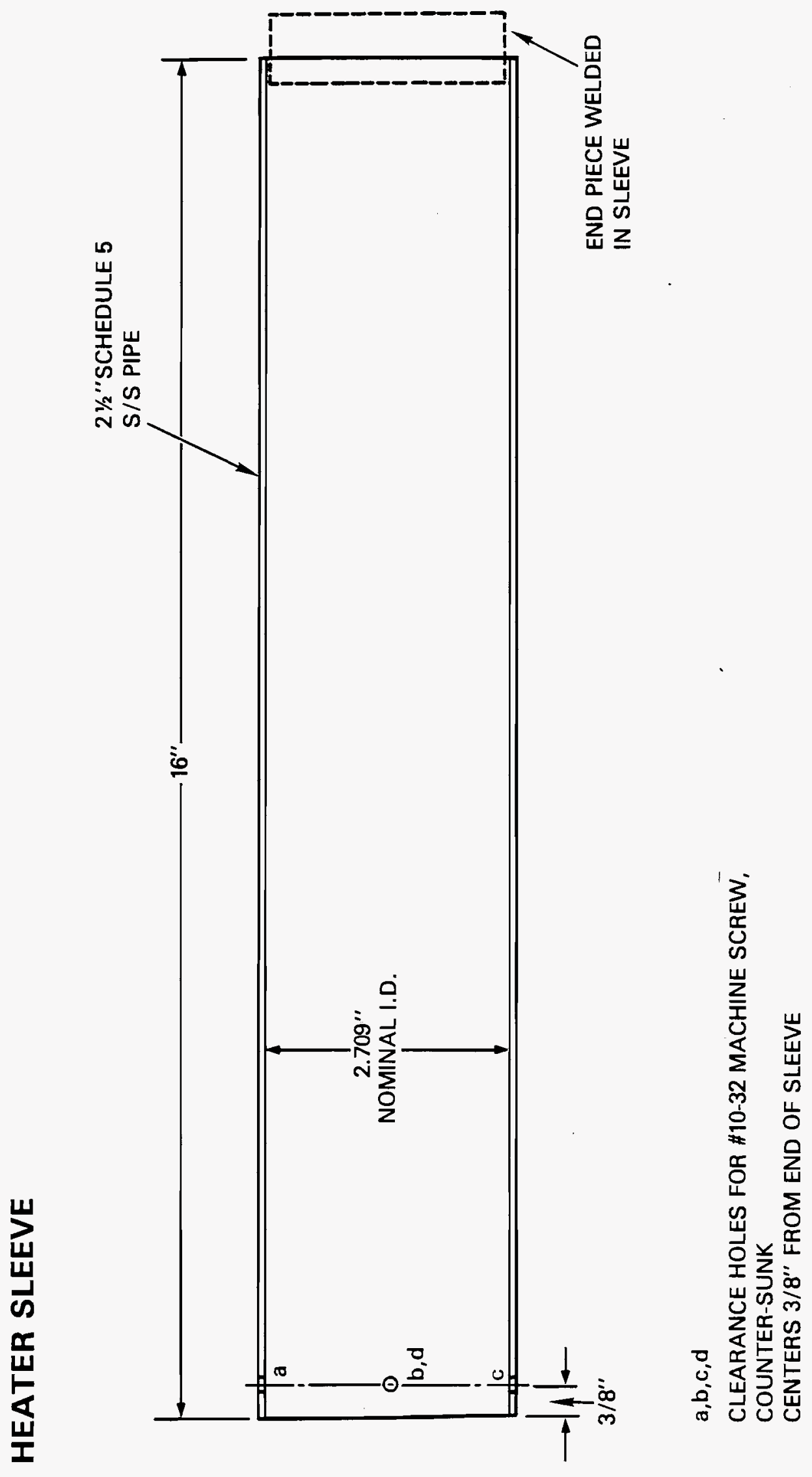

A. 12 


\section{HEATER SLEEVE END PIECE}
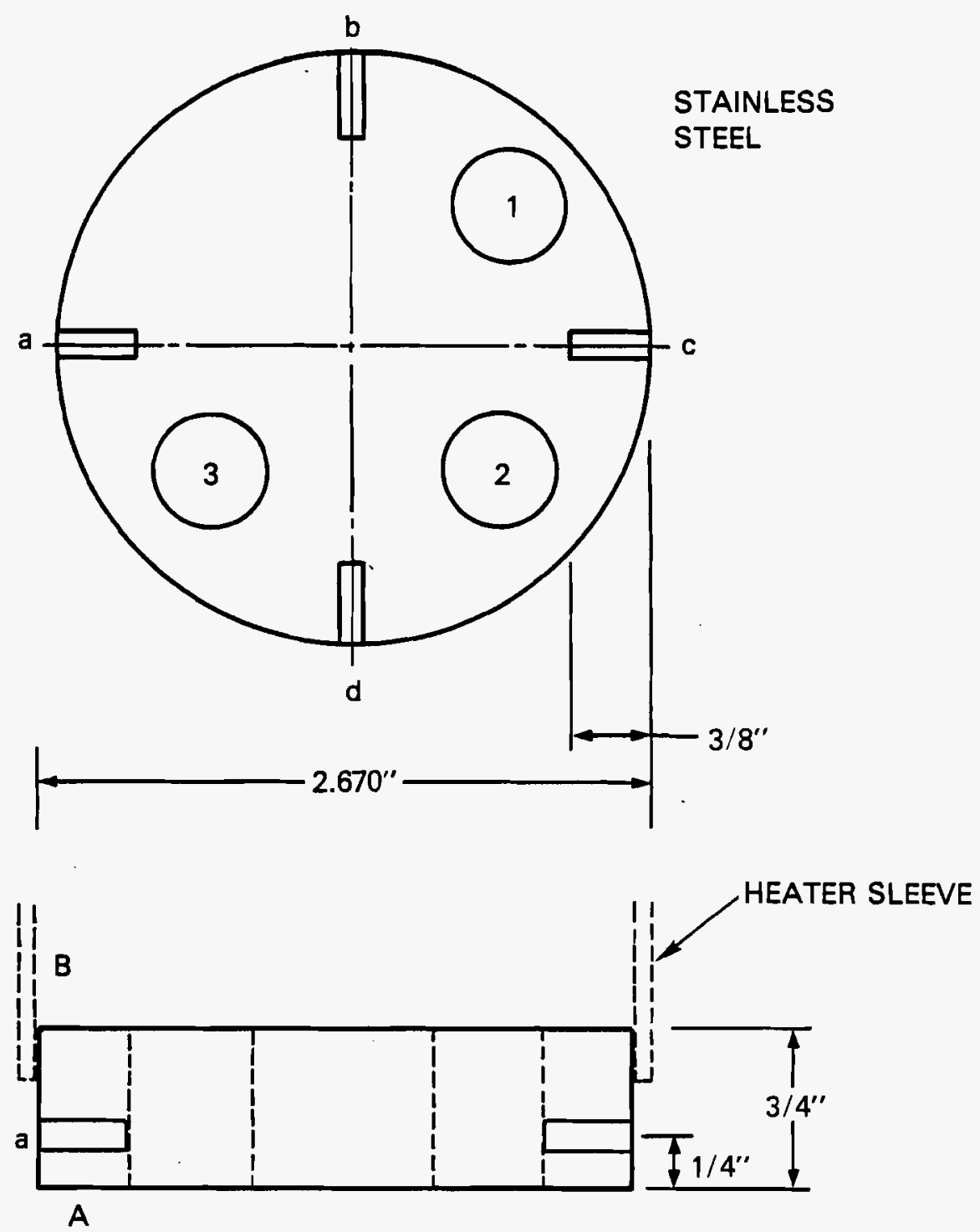

a,b,c,d - DRILL AND TAP FOR \#10-32 MACHINE SCREW,
3/8" DEEP

1,2,3 - DRILL, TAP FROM SIDE "A" FOR 1/8" NPT CENTERS 3/8" FROM OUTSIDE EDGE OF PIECE 


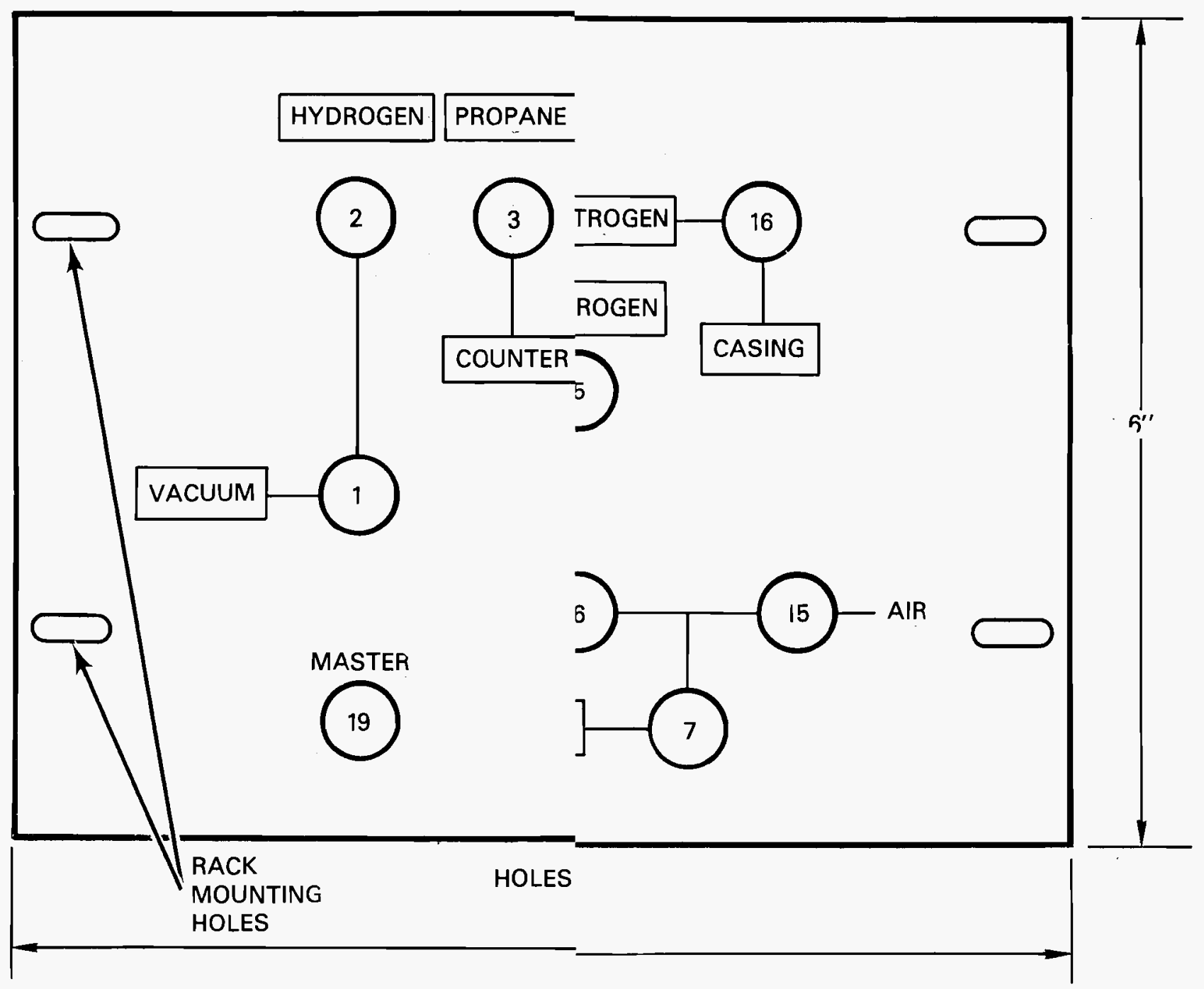


PNL-4069

UC-70

DISTRIBUTION

No. of

Copies

OFFSITE

A. A. Churm

DOE Chicago Patent Group

9800 South Cass Avenue

Argonne, IL 60439

27 DOE Technical Information Center

R. E. Cunningham

Office of Nuclear Safety Materials and Safeguards

Room 562

Nuclear Regulatory Commission

7915 Eastern Avenue

Silver Springs, MD 20910

2 Division of Waste Management

Nuclear Regulatory Commission

Washington, D.C. 20555

ATTN: J. B. Martin

R. D. Smith

W. E. Mott

DOE Division of Environmental

Control Technology

Washington, D.C. 20545

5 DOE Office of Nuclear Waste Management

Washington, D.C. 20545

ATTN: G. Oertel, NE-320, GTN

J. D. Dieckhoner, NE-321, GTN

D. J. McGoff, NE-320, GTN

C. A. Heath, NE-330, GTN

G. H. Daly

S. A. Mann

DOE Chicago Operations and

Region Office

Argonne, IL 60435

J. C. Bagby

USGS Water Resources Division

P.0. Box 2230

Idaho Falls, Idaho 83401
No. of

Copies

J. 0. Neff

DOE Columbus Program Office

505 King Avenue

Columbus, $\mathrm{OH} 43201$

2 DOE Idaho Operations Office

550 Second Street.

Idaho Falls, ID 83401

ATTN: J. P. Hamric

J. B. Whitsett

2 DOE Oak Ridge Operations Office

P. 0. Box E

Oak Ridge, TN 37830

ATTN: S. W. Ahrends

D. E. Large

2 DOE Savannah River Operations Office

P. 0. Box A

Aiken, SC 29801

ATTN: T. B. Hindman

R. P. Whitfield

2 DOE Albuquerque Operations Office

P. 0. Box 5400

Albuquerque, NM 87185

ATTN: R. Y. Lowrey

A. L. Taboas

S. G. Harbinson

DOE San Francisco Operations Office

1333 Broadway

Oak1 and, CA 94612

Environmental Protection Agency

Technological Assessment Division (AW-559)

Office of Radiation Programs

Washington, D. C. 20460 
PNL-4069

UC -70

No. of

Copies

5 C. Menninga

Dept. of Chemistry

Arizona State University

Tempe, Arizona 95281

2 Battelle Memorial Institute

505 King Avenue

Columbus, $\mathrm{OH} 43201$

ATTN: Beverly Rawles

Research Library

EG\&G Idaho

P. 0. Box 1625

Idaho Falls, ID 83415

ATTN: G. B. Levin

Robert Williams

Electric Power Research Inst.

3412 Hillview Avenue

Palo Alto, CA 94304

5 Oak Ridge National Laboratory

P. 0. Box X

Oak Ridge, TN 37830

ATTN: Central Research Library
A. L. Lotts
R. S. Lowrie
J. E. Vath
R. B. Fitts

William F. Holcomb

National Institute of Health

Radiation Safety Branch

Building 21

Bethesda, MD 20205

Allen M. Valentine Los Alamos National Laboratory MS-229

P. 0. Box 1663

Los Alamos, NM 87545

Allen J. Weiss

Dept. of Nuclear Energy

Brookhaven National Laboratory

Upton, NY 11973
No. of

Copies

2 Reynolds Electrical \& Engineering

P. 0. Box 14400

Las Vegas, NV 89114

ATTN: Paul Dickman

Gene Kenda 11

Preston H. Hunter

Ford, Bacon \& Davis

P. 0. Box 8009

Salt Lake City, Utah 84108

ONSITE

3 DOE Richland Operations Office

E. A. Bracken

H. E. Ransom

J. J. Schreiber

2 Rockwell Hanford Operations

J. H. Roecker

D. D. Wodrich

Westinghouse Hanford Company

A. G. Blasewitz

40 Pacific Northwest Laboratory

R. L. Brodzinski (20)

D. B. Cearlock

T. D. Chikalla

G. W. Gee

T. L. Jones

L. J. Kirby

J. M. Latkovich

J. M. Nielsen

R. E. Nightingale

A. M. Platt

J. V. Robinson

J. L. Swanson

H. H. Van Tuyl

N. A. Wogman

Technical Information (5)

Publishing Coordination (2) 